\title{
Growth and Yield Responses of Two Soybean Cultivars Grown under Controlled Groundwater Level in Southwestern Japan
}

\author{
Naoki Matsuo ${ }^{1}$, Motoki Takahashi ${ }^{2}$, Hiroshi Nakano ${ }^{1,3}$, Koichiro Fukami ${ }^{1}$, Shinori Tsuchiya ${ }^{1}$, \\ Satoshi Morita ${ }^{1}$, Hisashi Kitagawa ${ }^{1}$, Keiko Nakano ${ }^{1}$, Hiroaki Nakamoto ${ }^{4}$ and Kohei Tasaka ${ }^{1}$ \\ ('NARO Kyushu Okinawa Agricultural Research Center, 496 Izumi, Chikugo, Fukuoka 833-0041, Japan; \\ ${ }^{2}$ NARO Kyushu Okinawa Agricultural Research Center, 2421 Suya, Koushi, Kumamoto 861-1192, Japan; \\ ${ }^{3}$ NARO Institute of Crop Science, 2-1-18 Kannondai, Tsukuba, Ibaraki 305-8518, Japan; \\ ${ }^{4}$ Fukuoka Women's Junior College, 4-16-1 Gojo, Dazaifu, Fukuoka 818-0193, Japan)
}

\begin{abstract}
One of the limiting factors of soybean yield in southwestern Japan is soil moisture fluctuation from flooding to drought. The Farm-Oriented Enhancing Aquatic System (FOEAS), which consists of underdrain and sub-irrigation systems and can keep groundwater levels stable, was developed in 2005 to solve this problem. To obtain basic information on soybean cultivation using the FOEAS in southwestern Japan, we examined the growth response to groundwater level by using two cultivars (cv. Fukuyutaka and Sachiyutaka) in 2008 and 2010. Plant growth, yield, yield components and seed components (protein and oil contents) were analyzed. We also studied the effect of sowing time (normal or late). The groundwater level was controlled at depths of 20 and $35 \mathrm{~cm}$ or not treated (NT) as a control. The groundwater level could be kept at the target depths $(20$ and $35 \mathrm{~cm})$ by FOEAS throughout the experimental period, but that in the NT plot fluctuated greatly. The growth and yield of Sachiyutaka might be increased by FOEAS, especially in late sowing, but the yield of normal sown Sachiyutaka was decreased in the $20-\mathrm{cm}$ plot in 2010 . Yield of late-sown Fukuyutaka tended to be decreased in the $20-\mathrm{cm}$ plot. These results suggest that (1) the optimum groundwater level for yield of Sachiyutaka is between 20 and $35 \mathrm{~cm}$, regardless of sowing time and (2) the groundwater level should not be kept at $20 \mathrm{~cm}$ for late-sown Fukuyutaka. Further studies are needed to determine the optimum groundwater level for each cultivar.
\end{abstract}

Key words: Drainage, Farm-Oriented Enhancing Aquatic System, Groundwater Level, Seed Component, Soybean, Sub-irrigation, Yield.

The soybean is a traditional crop in Japan and is processed into traditional foods such as tofu (e.g., Murphy et al., 1997; Zarkadas et al., 1997). In Japan, more than $80 \%$ of soybeans are cultivated in fields converted from paddy fields (Araki, 2006; Hamaya et al., 2007). Paddy fields are originally constructed to receive irrigation water to cultivate paddy rice. Therefore, the drainage in paddy fields is generally poor, mainly due to hardpans that exist at approximately $20-\mathrm{cm}$ depth from the soil surface. Because the optimal sowing time coincides with the rainy season (from mid-June to mid-July) in southwestern Japan, transient waterlogging is one of the environmental factors which reduce germination rates or vegetative growth, resulting in a yield penalty. Soybean is especially vulnerable to pre-germination waterlogging (Arihara et al., 2000). When the germination is strictly inhibited by waterlogging, farmers must re-sow. This is a waste of seed, fuel and labor.
Furthermore, if rainfall continues until late July, farmers must sow seeds after the rainy season. Late sowing cultivation reduces the period of vegetative growth, resulting in a yield penalty (Uchikawa et al., 2009). In addition to flooding stress, drought stress that often occurs after the rainy season (usually from late July to August) also decreases the vegetative growth of normally sown plants and the germination rate and vegetative growth of late-sown plants (Uchikawa et al., 2003). Therefore, the fluctuation of soil water status (from flooding to drought) is the environmental characteristic under which soybean is cultivated in southwestern Japan and may limit soybean yield.

A groundwater level control system, called the FarmOriented Enhancing Aquatic System (FOEAS), was developed in 2005 (Paddy Research Co., Ltd, Miyagi, Japan: Wakasugi and Fujimori, 2009). This system consists of underdrain and sub-irrigation systems and can control

Received 8 December 2011. Accepted 17 July 2012. Corresponding author: N. Matsuo (matsuon@affrc.go.jp, fax +81-942-53-7776).

Abbreviations: DAS, days after sowing; FOEAS, Farm-Oriented Enhancing Aquatic System; SWP, soil water potential. 
the groundwater level at the desired depth from about -30 to $+10 \mathrm{~cm}$ below the soil surface. Crop rotation systems are widespread in southwestern Japan. One of the serious problems in performing crop rotation is the overlap of agricultural work between the preparation of summer crops (rice or soybeans) and the harvest of winter crops (wheat or barley) in June (rainy season). This overlap is caused by the uncertain rainfall in the rainy season, which delays the harvesting of winter crops at the proper time. Because FOEAS can control soil moisture conditions appropriately, it can improve the working efficiency of farm machines, which can facilitate crop rotation in southwestern Japan.

The effects of groundwater level on the growth, yield and physiology of the soybean have been reported. Mejia et al. (2000) conducted field experiments in the USA with groundwater level management similar to that employed in FOEAS. They attempted to maintain the groundwater level at depths of 50 and $75 \mathrm{~cm}$ and reported that a significantly higher soybean yield was obtained in both treatments than without groundwater level management. In a greenhouse experiment, Nathanson et al. (1984) reported that a groundwater level at depths of 3 or $15 \mathrm{~cm}$ increased seed yield as compared with the treatment keeping the soil moisture above the field water capacity. By a similar method, Hunter et al. (1980) demonstrated that soybean plants grown under a groundwater level of $15 \mathrm{~cm}$ accumulated $37 \%$ more dry matter and 35 times more nodule dry matter than normally irrigated control plants. Shimada et al. $(1995,1997)$ investigated the effects of the groundwater table on the shoot growth, yield, photosynthesis, stomatal conductance and leaf water potential of soybeans in lysimeter experiments in Japan. They demonstrated that the effects of the groundwater level on those parameters differed with the year and depended largely on rainfall patterns; a groundwater level of $40 \mathrm{~cm}$ increased those parameters as compared with groundwater levels of 10 and $70 \mathrm{~cm}$ when the rainfall amount was small, while a groundwater level of $70 \mathrm{~cm}$ increased them when the rainfall amount was large. As for soybean cultivation in FOEAS, Shimada et al. (2006, 2009, 2012) conducted several field experiments in the Kanto region, Eastern Japan. They reported that when the groundwater level was kept at about 20 or $32 \mathrm{~cm}$, the relative ureide abundance (i.e., nodule activity) and photosynthetic parameters were greater than those in the control (converted paddy field with natural rainfall). This resulted in a higher seed yield in FOEAS than in the conventional cultivation method (i.e., soybeans are cultivated under converted paddy fields without drainage and irrigated by natural rainfall). They also reported that soybean (cv. Tachinagaha) yield with a groundwater level of $32 \mathrm{~cm}$ tended to be higher than that with a groundwater level of $20 \mathrm{~cm}$.
In this way, FOEAS has the potential not only to increase soybean yield but also to facilitate the crop rotation systems in southwestern Japan, and thus is expected to prevail in this region. It is important to understand the effect of the interaction between the groundwater level and cultivation methods on the growth and yield of soybeans in southwestern Japan and to clarify whether their interactions vary with the cultivar. Although several years have passed since FOEAS was developed, the available information on the usage of FOEAS in southwestern Japan is still limited because the climate, cultivar and cultivation methods in southwestern Japan are different from those in the Kanto region. The objectives of this study were to examine the effects of groundwater level, sowing time, cultivar and their interaction on the growth and yield of soybeans (cv. Fukuyutaka and Sachiyutaka) in FOEAS to obtain basic information on the usage of FOEAS in southwestern Japan. We also analyzed their effects on seed components, because seed component is one of the important agronomic traits, especially for processing tofu. Since sowing time greatly affects soybean yield in southwestern Japan, we also changed the sowing time as part of the cultivation method in this study.

\section{Materials and Methods}

\section{Site description and plant materials}

Field experiments were conducted in 2008 and 2010 at the Kyushu Okinawa Agricultural Research Center (KARC), Chikugo, Fukuoka, Japan $\left(33^{\circ} 12^{\prime} \mathrm{N}, 130^{\circ} 30^{\prime} \mathrm{E}\right.$, $10 \mathrm{~m}$ elevation). At the KARC, there are three FOEASs. The soil was lowland paddy soil (Typic Endoaquept), and the previous crops were wheat and rice in 2008 and 2010, respectively. The soybean cultivars used were Fukuyutaka (maturity group; VI) and Sachiyutaka (maturity group; V). The former was released in 1980 and cultivated widely in southwestern Japan, and the latter was released in 2001 and gradually spread around this region.

\section{Crop management}

In both years, soybeans were grown in the same field. An experiment was conducted in three environments consisting of controlled groundwater level at depths of 20 (20-cm plot) and $35 \mathrm{~cm}$ (35-cm plot). Groundwater level for the control treatment was not treated (i.e., only the underdrain was used) (NT plot). In each environment, the treatment was a split-plot arranged in a randomized complete design with three replications. The main plot consisted of sowing time and subplot consisted of cultivar. The area of each FOEAS and each replication was at least $360 \mathrm{~m}^{2}$ and $14.4 \mathrm{~m}^{2}$, respectively. FOEAS was constructed in the same field and the distance between groundwater treatments was about $3 \mathrm{~m}$. The water movement between treatments and seepage was inhibited by compacting the soil and by burying vinyl sheets at a depth of more than 60 
$\mathrm{cm}$. The groundwater treatment was applied just after sowing to late October in both years, because the irrigation water around KARC was turned off during this period. Seeds were sown at the normal or late sowing time. Three seeds of each cultivar were sown at a spacing of $75 \mathrm{~cm} \times 25$ $\mathrm{cm}$ on 8 July in 2008 and on 16 July in 2010 for the normal sowing time and at a spacing of $37.5 \mathrm{~cm} \times 25 \mathrm{~cm}$ on 30 July in 2008 and 2010 for the late sowing. Because the period of vegetative growth was shorter for the late sowing than in the normal sowing time, the planting density was increased for the late sowing to ensure the biomass per unit area. Seedlings were thinned to two plants per hill after establishment. For the normal sowing time, intertillage and ridging (called "baido"), a normal practice in Japan to control lodging and weeds (Wada et al., 2006), were carried out at about $25 \mathrm{~d}$ after sowing (DAS) in both years. The fields received $50 \mathrm{~kg} \mathrm{ha}^{-1} \mathrm{P}_{2} \mathrm{O}_{5}$ and $50 \mathrm{~kg} \mathrm{ha}^{-1} \mathrm{~K}_{2} \mathrm{O}$ in the form of chemical fertilizer, and $1000 \mathrm{~kg} \mathrm{ha}^{-1}$ magnesium lime were applied by hand $1 \mathrm{~d}$ before sowing. No additional fertilizer was applied. A combination of insecticide, herbicide and manual weed control was used to maximize the yield.

\section{Measurements}

Daily weather data were collected from the KARC meteorological station within $100 \mathrm{~m}$ of the experimental field. Daily soil water potential (SWP) at depths of 10 and $30 \mathrm{~cm}$ was measured with tensiometers (HD-001, Sensez Co., Ltd. Tokyo, Japan). We measured the SWP only for Fukuyutaka (both normal and late sowing treatments), due to the limitation of the number of tensiometers. In 2008, large holes were dug in each groundwater level treatment down to about $100 \mathrm{~cm}$ from the soil surface, and the groundwater level was measured daily with a ruler once per day. Therefore, we could measure the groundwater level to a depth of about $100 \mathrm{~cm}$. In 2010, polyvinyl chloride pipes (inner diameter, $10 \mathrm{~cm}$; height, $60 \mathrm{~cm}$ ) were installed down to approximately $55 \mathrm{~cm}$ in each groundwater level treatment, and the daily groundwater level was measured with water-level loggers (U20-001-04, Onset Computer Corp., Bourne, MA, USA). These parameters were measured at the central position of the main plot $(20 \mathrm{~cm}, 35 \mathrm{~cm}$ and NT). Due to the limitation of the number of instruments, no replications were performed for the SWP and groundwater level measurements. The recording intervals were 15 and $60 \mathrm{~min}$ for tensiometers and groundwater-level loggers, respectively. Data were averaged and shown on a daily basis. Because the measuring limit of the groundwater level was $55 \mathrm{~cm}$ in 2010, groundwater level data below $55 \mathrm{~cm}$ indicate that the actual groundwater level was lower than the values presented.

Crop samples were collected at 21 DAS, R1 (beginning bloom, Fehr et al., 1971), around R4 [stage when the leaf
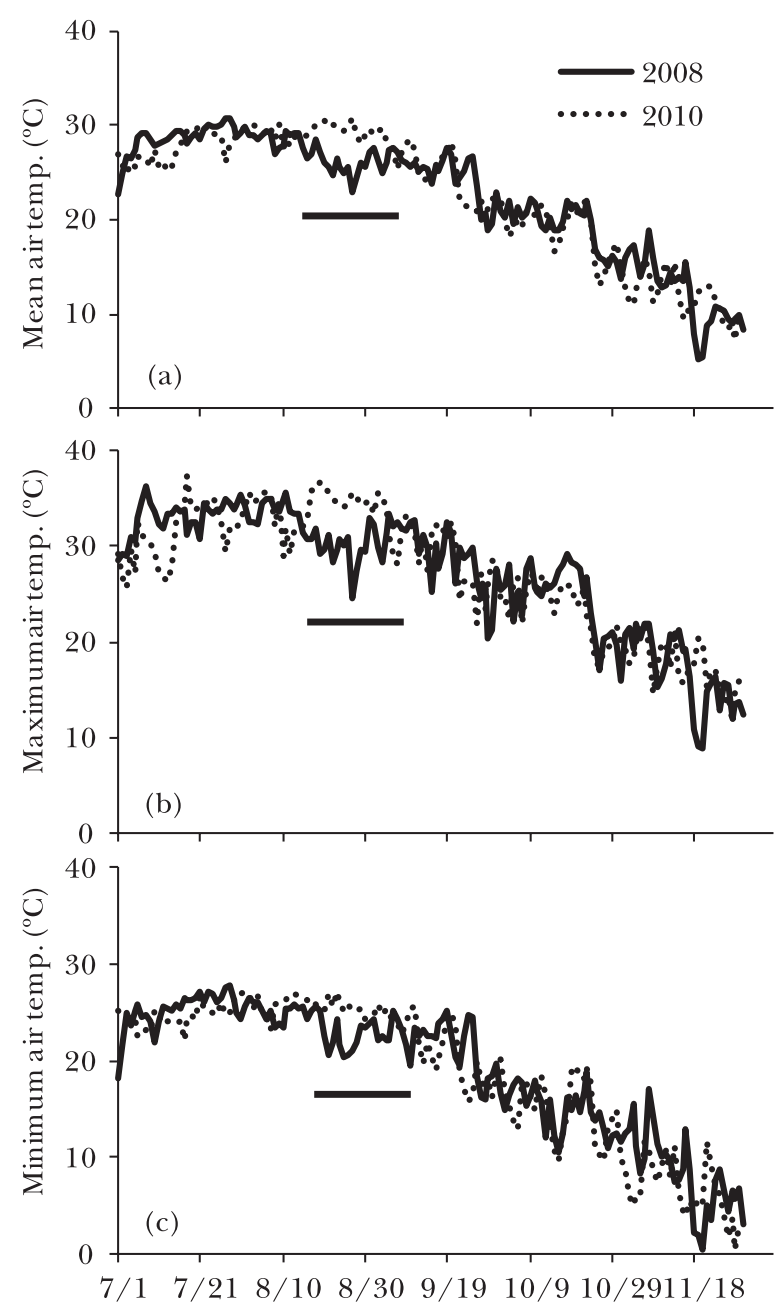

Fig. 1. Mean (a), mean maximum (b) and mean minimum (c) air temperatures in 2008 (solid lines) and 2010 (dotted lines). Bars in figures indicate the period during which air temperature was higher ( $2^{\circ} \mathrm{C}$ on average) in 2010 than in 2008.

area index (LAI) reaches its maximum], and R6 (full-size seed in the top four nodes) to determine total shoot dry weight and LAI. The plants in a $0.94 \mathrm{~m}^{2}$ area per replication were collected at each sampling. LAI was determined with a leaf area meter (LI-3000C, LI-COR, Lincoln, NE, USA). Then, shoot dry weight (SDW) was determined after oven-drying at $80^{\circ} \mathrm{C}$ for at least $3 \mathrm{~d}$. At maturity, the plants in a $3.4 \mathrm{~m}^{2}$ area per replication were sampled to determine the yield and yield components (i.e., the number of pods per $\mathrm{m}^{2}$, the number of seeds per pod and the 100-seed weight). The crude protein and oil content of the seeds were determined by near-infrared spectroscopic analysis (Infratec ${ }^{\mathrm{TM}} 1241$ Seed Analyser, Foss Tecator AB, Högänas, Sweden). The conversion factor for the calculation of the protein content was 6.25.

\section{Statistical analysis}

Statistical analysis was performed using SPSS (SPSS 19.0, SPSS Inc., Chicago, IL). For each groundwater 


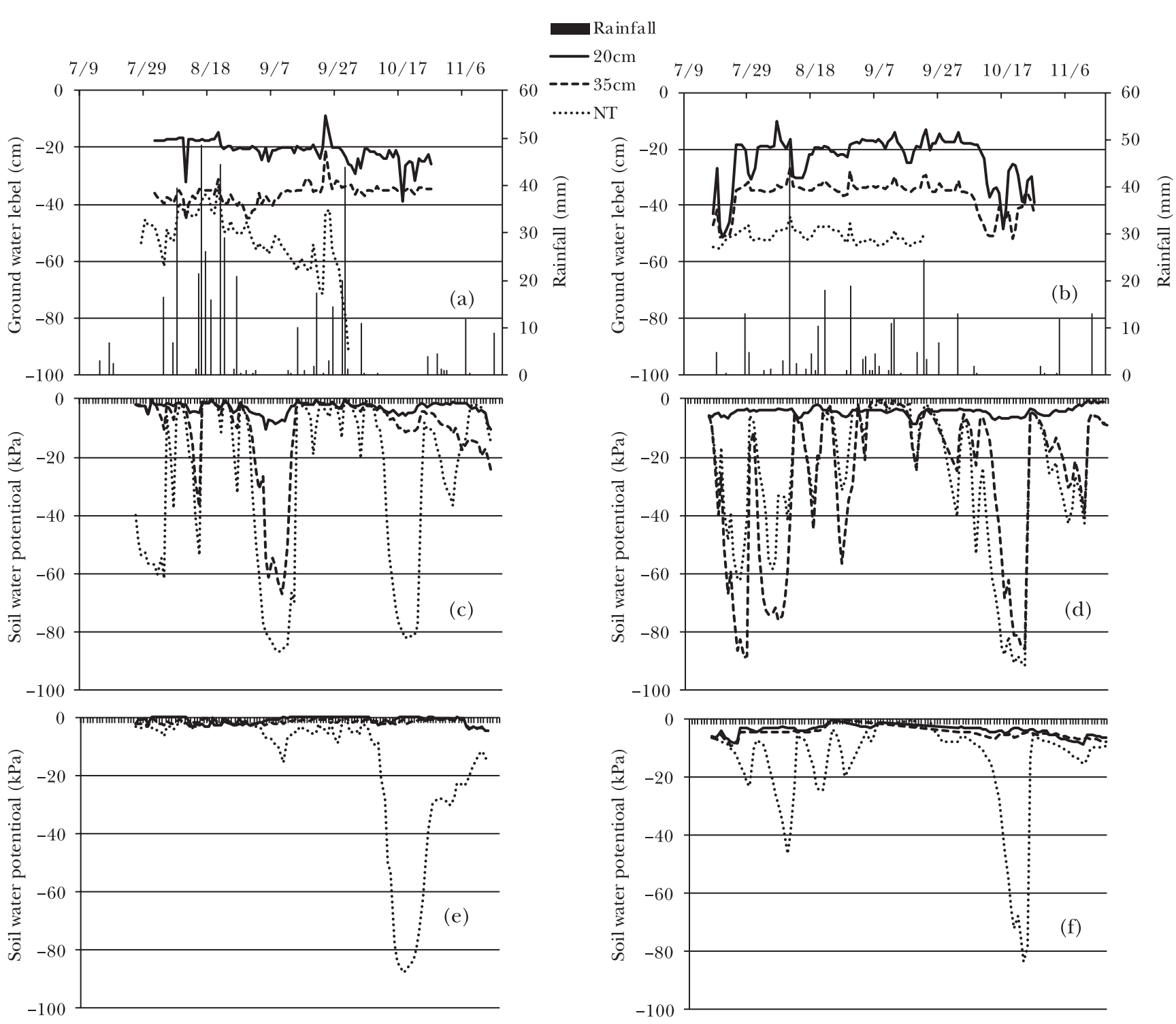

Fig. 2. Rainfall and groundwater level (a, b), and soil water potential at depths of 10 (c, d) and $30 \mathrm{~cm}$ (e, f) in each groundwater level treatment in 2008 (a, c, e) and 2010 (b, d, f). Solid, dashed and dotted lines indicate 20-cm, 35-cm and NT plots, respectively. Because groundwater level in NT plot could not be measured after late September, data for groundwater level in NT after late September are not shown.

treatment and year, the analysis of variance (ANOVA) was performed to test the effects of sowing time and cultivar and their interactions on yield, yield components and seed components by using a general linear model. Sowing time, cultivar and their interactions were considered fixed effects, and replication within a year was considered a random effect. Means were separated by using Fisher's protected LSD if the F-test of ANOVA exceeded the 0.05 probability level.

\section{Results}

\section{Weather, groundwater level and SWP}

The mean air temperatures in July and November of 2010 were lower than the respective levels in 2008, and those in August and October of 2010 were higher than those in 2008 (data not shown). The mean, mean maximum and mean minimum air temperatures in 2010, especially between mid-August and mid-September, were about $2^{\circ} \mathrm{C}$ higher than those in 2008 (Fig. 1).

The amounts of precipitation during cultivation in 2008 and 2010 were 452 and $254 \mathrm{~mm}$, respectively (Fig. 2a, b). In 2008, the rainfall was concentrated around mid-August and late September. In both years, the amount of rainfall was small from early to late October. The groundwater level in the NT plot in 2008 was highest $(40 \mathrm{~cm})$ around mid-August and decreased thereafter. The groundwater level decreased to lower than $100 \mathrm{~cm}$ in the NT plot after 10 October and the level is not shown in Fig. 2a. In both years, the groundwater level could be controlled at target levels until mid-October in the 20- and 35-cm treatments. The SWP in normal and late sowing treatments were similar in both years, and the values in normal sowing time 

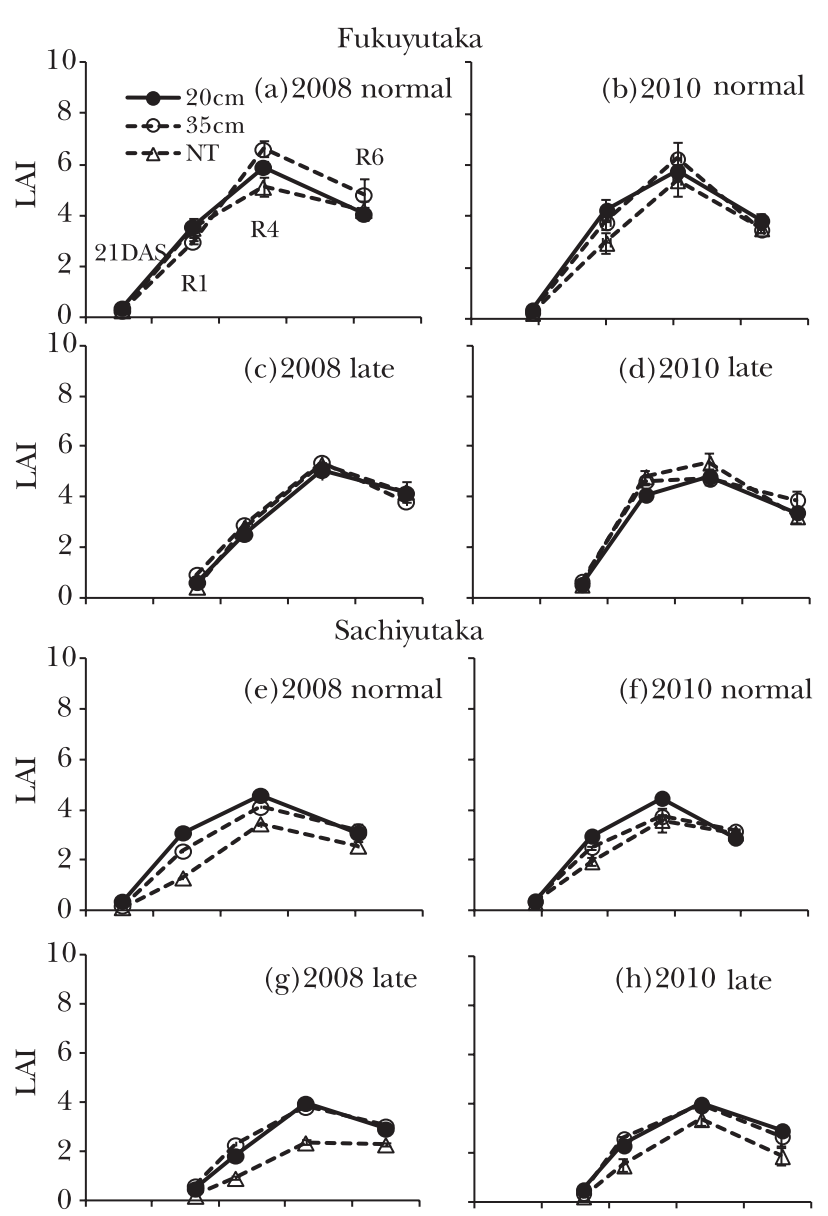

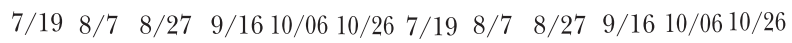

Fig. 3. Leaf area index (LAI) of Fukuyutaka (a, b, c, d) and Sachiyutaka $(e, f, g, h)$ in normal $(a, b, e, f)$ and late $(c, d, g, h)$ sowing treatments in 2008 (a, c, e, g) and 2010 (b, d, f, h) at 21 DAS, R1, R4 and R6. Closed circles, open circles and open triangles indicate $20-\mathrm{cm}, 35-\mathrm{cm}$ and NT plots, respectively. Data are shown as means \pm S.E. $(n=3)$.

of Fukuyutaka were presented in Fig. 2. In both years, the SWP at a depth of 10 and $30 \mathrm{~cm}$ in the $20-\mathrm{cm}$ treatments was higher than $-10 \mathrm{kPa}$ throughout the experiments (Figs. 2c, d, e, f). SWP at a depth of $10 \mathrm{~cm}$ in the 35-cm and NT plots was lower than that in the $20-\mathrm{cm}$ treatment. SWP at a depth of $10 \mathrm{~cm}$ in 2010 fluctuated greatly as compared with that in 2008 (Fig. 2c, d). In both years, SWP at a depth of $30 \mathrm{~cm}$ in the $35-\mathrm{cm}$ treatment was higher than $-10 \mathrm{kPa}$, as observed in the 20-cm treatment (Fig. 2e, f). In 2008, SWP at a depth of $30 \mathrm{~cm}$ in the NT plot was above $-20 \mathrm{kPa}$ until mid-October, although that in 2010 fell below -20 $\mathrm{kPa}$ four times until mid-October (Fig. 2e, f). In both years, SWP at a depth of $30 \mathrm{~cm}$ in the NT plot fell below $-80 \mathrm{kPa}$ around mid-October (Fig. 2e, f).

\section{Plant growth}

LAI and SDW are shown in Fig. 3 and Fig. 4, respectively. In Fukuyutaka sown at the normal time, LAI was higher in the 35-cm plot than in the NT plot at R4 in 2008 (Fig. 3a)
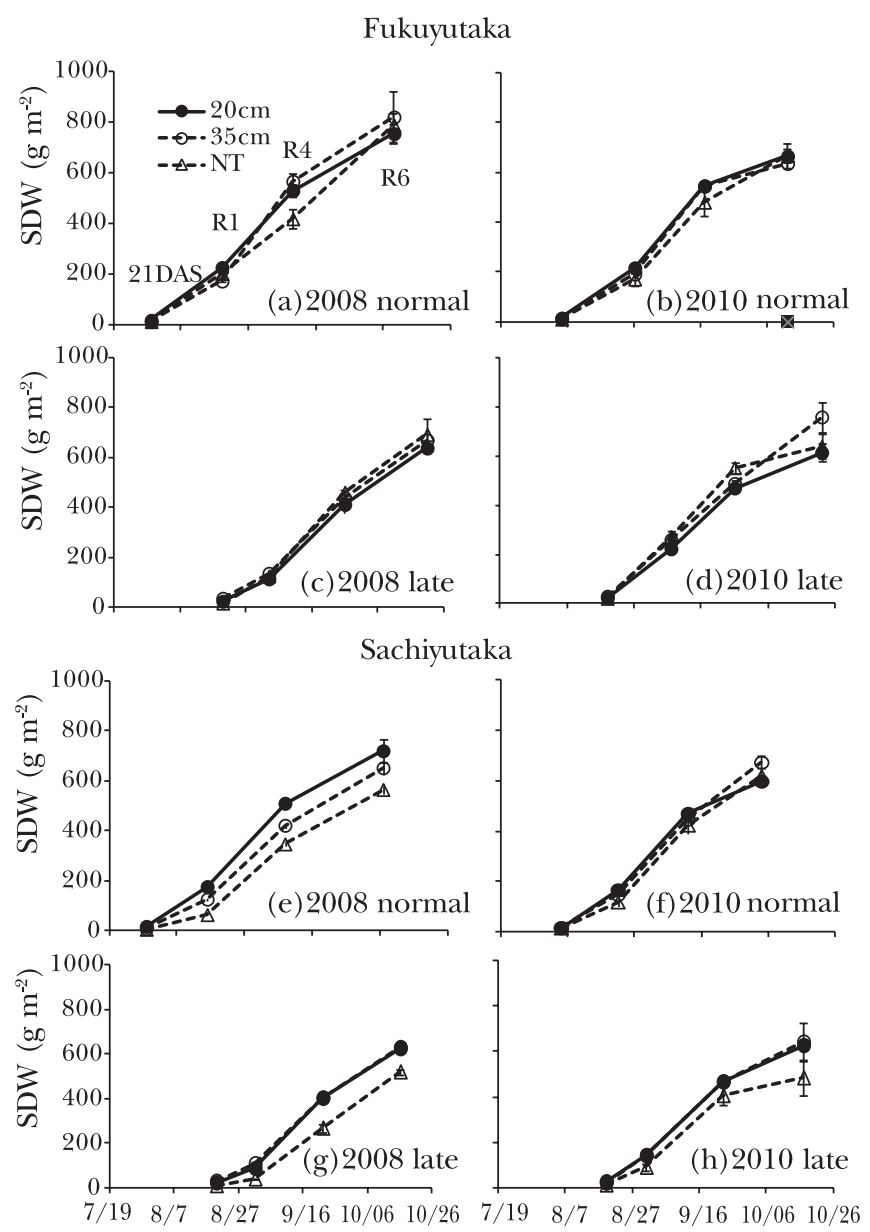

Fig. 4. Shoot dry weight (SDW) of Fukuyutaka (a, b, c, d) and Sachiyutaka (e, f, g, h) in normal (a, b, e, f) and late (c, d, g, h) sowing treatments in 2008 (a, c, e, g) and 2010 (b, d, f, h) at 21 DAS, R1, R4 and R6. Closed circles, open circles and open triangles indicate $20-\mathrm{cm}, 35-\mathrm{cm}$ and NT plots, respectively. Data are shown as means \pm S.E. $(\mathrm{n}=3)$.

and LAI was higher in the 20-cm plot than in the NT plot at R1 in 2010 (Fig. 3b). In the late-sown Fukuyutaka, LAI tended to be higher in the $35-\mathrm{cm}$ plot than in the $20-\mathrm{cm}$ and NT plot at R1 in 2008 (Fig. 3c). In 2010, late-sown Fukuyutaka in the 35 -cm plot had a higher LAI than that in the $20-\mathrm{cm}$ and NT plots at 21 DAS, although LAI in the NT plot was higher than that in the $20-\mathrm{cm}$ plot at R1 and R4 (Fig. 3d). In Sachiyutaka sown at the normal time, LAI was the highest in the $20-\mathrm{cm}$ plot, followed by the $35-\mathrm{cm}$ and NT plots until R4, but differences among groundwater conditions were not observed at R6 in 2008 (Fig. 3e). In 2010, a difference among groundwater conditions in LAI of Sachiyutaka in normal sowing time was observed at R1 and R4 (Fig. 3f). In late-sown Sachiyutaka, LAI in the NT plot was lower than that in the other plots until R6 in 2008 (Fig. 3g) and similar trends were observed in 2010 (Fig. $3 \mathrm{~h})$.

In Fukuyutaka, in normal sowing time, SDW tended to be lighter in the NT plot than in the other plots until R4, 
but there was little difference among groundwater conditions at R6 in 2008 (Fig. 4a). There were no differences in the SDW of Fukuyutaka sown at the normal time throughout the season in 2010 (Fig. 4b). In late-sown Fukuyutaka, no differences were detected in SDW among groundwater conditions in 2008 (Fig. 4c). The SDW of late-sown Fukuyutaka tended to be higher in the NT plot than in the 20-cm plot at 21 DAS and R4 in 2010 (Fig. 4d). In 2008, SDW of Sachiyutaka was lighter in the NT plot than in the 20- and 35-cm plots throughout the season, regardless of sowing time (Fig. 4e, g). In 2010, SDW was heavier in the $20-\mathrm{cm}$ plot than in the NT plot at R1 in the normal sowing time (Fig. 4f) and at 21 DAS and R1 in the late-sowing time (Fig. 4h).

\section{Yield and yield components}

In 2008, a significant $(\mathrm{P}<0.05)$ cultivar difference in yield was detected in the NT plot and Fukuyutaka had a larger yield than Sachiyutaka (Table 1). A significant $(\mathrm{P}<0.05)$ cultivar $\times$ sowing treatment interaction on yield was detected in the 35-cm plot and late-sown Fukuyutaka had a larger yield than late-sown Sachiyutaka, but a significant cultivar difference was not observed at a normal sowing time. There was no significant difference in yield with the sowing time under any groundwater conditions.

A significant $(\mathrm{P}<0.05)$ cultivar $\times$ sowing time interaction on the number of filled pods $\mathrm{m}^{-2}$ was detected in all groundwater conditions. The number of filled pods $\mathrm{m}^{-2}$ of Fukuyutaka in normal sowing time was larger than that in late-sowing, while there was no significant difference among sowing treatments in Sachiyutaka. Fukuyutaka had a larger number of filled pods $\mathrm{m}^{-2}$ than Sachiyutaka irrespective of sowing time and groundwater condition, except for late sowing in the $20-\mathrm{cm}$ plot.

The number of seeds per pod tended to be larger in Sachiyutaka than in Fukuyutaka in all groundwater conditions. In the $35-\mathrm{cm}$ plot, a significant $(\mathrm{P}<0.05)$ cultivar $\times$ sowing time interaction on the number of seeds per pod was found. The number of seeds per pod of Fukuyutaka in late sowing was larger than that in normal sowing time, while the number of seeds per pod of Sachiyutaka in normal sowing time was larger than that in late sowing.

In all groundwater conditions, a significant $(\mathrm{P}<0.05)$ cultivar $\times$ sowing time interaction on 100 -seed weight was found and 100-seed weight of Fukuyutaka in late sowing was significantly heavier than that in normal sowing time. In the 20-cm and NT plots, 100-seed weight of Sachiyutaka was significantly heavier than that of Fukuyutaka in normal sowing time, while there was no cultivar difference in late sowing. In the 35-cm plot, 100-seed weight of Sachiyutaka was significantly higher than that of Fukuyutaka irrespective of sowing time.

Yield and yield components were lower in 2010 than in 2008 (Tables 1 and 2). In the 20-cm and NT plots, a significant $(\mathrm{P}<0.05)$ cultivar $\times$ sowing time interaction on yield was observed. In the 20-cm plot, yield of Fukuyutaka was larger in normal sowing time than in late sowing, while no difference was observed in Sachiyutaka. In normal timesown plants, there was no significant difference in yield with the cultivar, but late-sown Sachiyutaka had a significantly $(\mathrm{P}<0.05)$ larger yield than late-sown Fukuyutaka. In the NT plot, in normal sowing time Sachiyutaka had a significantly larger yield than late-sown Sachiyutaka, while there was no difference in yield with the sowing time in Fukuyutaka. Normal time-sown Sachiyutaka had a significantly larger yield than normal sowing time Fukuyutaka, but there was no difference in yield in latesown plants. In the 35-cm plot, Sachiyutaka had a larger yield than Fukuyutaka irrespective of sowing time and there was no difference in the yield with the sowing time in either cultivar.

No significant main effect of cultivar and sowing time on the number of filled pods $\mathrm{m}^{-2}$ was found. There was no significant cultivar $\times$ sowing time interaction on the number of filled pods $\mathrm{m}^{-2}$ in all groundwater conditions, except the $20 \mathrm{~cm}$ plot. In this condition, the number of filled pods $\mathrm{m}^{-2}$ of Fukuyutaka in normal sowing time was larger than that in late sowing, while a countertrend was observed in Sachiyutaka. In normal sowing time, Fukuyutaka had a larger number of filled pods $\mathrm{m}^{-2}$ than Sachiyutaka, but Sachiyutaka had a larger number of filled pods $\mathrm{m}^{-2}$ than Fukuyutaka in late sowing.

The number of seeds per pod tended to be larger in Sachiyutaka than in Fukuyutaka in all groundwater conditions. A significant $(\mathrm{P}<0.05)$ cultivar $\times$ sowing time interaction on the number of seeds per pod was found only in the 20-cm plot. In normal sowing time, Sachiyutaka had a larger number of seeds per pod than Fukuyutaka, while Fukuyutaka had a larger number of seeds per pod than Sachiyutaka in late sowing.

In all groundwater conditions, the 100-seed weight tended to be heavier in Sachiyutaka and in normal sowing time than in Fukuyutaka and in late sowing. A significant $(\mathrm{P}<0.05)$ cultivar $\times$ sowing time interaction on 100 -seed weight was found only in the NT plot. In the NT plot, Sachiyutaka had a heavier 100 -seed weight than Fukuyutaka irrespective of sowing time, but the cultivar difference was larger in normal sowing time than that in late sowing.

\section{Protein and oil contents}

In 2008, there was a significant $(\mathrm{P}<0.05)$ cultivar $\times$ sowing time interaction on protein content in the $35-\mathrm{cm}$ and NT plots (Table 1). Protein content of Sachiyutaka was higher in late sowing than in normal sowing time, especially in 35$\mathrm{cm}$ and NT plots, while the effect of sowing time on protein content of Fukuyutaka was not significant. In contrast, oil content of Sachiyutaka in normal sowing time 
Table 1. Effects of sowing time and cultivar on yield, yield components and seed components at each groundwater level in 2008.

\begin{tabular}{|c|c|c|c|c|c|c|c|c|}
\hline Groundwater & Cultivar & Sowing time & $\begin{array}{c}\text { Yield } \\
\left(\mathrm{g} \mathrm{m}^{-2}\right)\end{array}$ & $\begin{array}{c}\text { No. of filled } \\
\text { pod } \mathrm{m}^{-2}\end{array}$ & $\begin{array}{c}\text { No. of seed } \\
\text { per pod }\end{array}$ & $\begin{array}{c}\text { 100-seed } \\
\text { weight }(\mathrm{g})\end{array}$ & $\begin{array}{c}\text { Protein content } \\
(\%)\end{array}$ & $\begin{array}{c}\text { Oil content } \\
(\%)\end{array}$ \\
\hline \multirow[t]{11}{*}{$20 \mathrm{~cm}$} & Fukuyutaka & & 432 & 763 & 1.72 & 33.3 & 46.5 & 19.3 \\
\hline & Sachiyutaka & & 402 & 623 & 1.80 & 35.9 & 47.2 & 19.0 \\
\hline & LSD (0.05) & & $\mathrm{ns}^{\mathrm{b}}$ & 69 & 0.05 & 1.1 & ns & ns \\
\hline & & Normal & 430 & 745 & 1.73 & 33.9 & 46.4 & 19.6 \\
\hline & & Late & 403 & 641 & 1.78 & 35.4 & 47.3 & 18.7 \\
\hline & & LSD (0.05) & ns & 69 & ns & ns & ns & ns \\
\hline & Fukuyutaka & Normal & 460 & 869 & 1.68 & 31.6 & 46.3 & 19.7 \\
\hline & & Late & 403 & 656 & 1.75 & 35.1 & 46.7 & 19.0 \\
\hline & Sachiyutaka & Normal & 401 & 621 & 1.79 & 36.2 & 46.4 & 19.5 \\
\hline & & Late & 403 & 626 & 1.81 & 35.7 & 47.9 & 18.4 \\
\hline & & LSD $(0.05)$ & ns & 97 & ns & 1.5 & ns & ns \\
\hline \multirow[t]{11}{*}{$35 \mathrm{~cm}$} & Fukuyutaka & & 422 & 760 & 1.72 & 32.3 & 46.5 & 19.2 \\
\hline & Sachiyutaka & & 397 & 609 & 1.78 & 36.6 & 47.2 & 18.9 \\
\hline & LSD $(0.05)$ & & 13 & 26 & 0.04 & 0.5 & ns & ns \\
\hline & & Normal & 405 & 706 & 1.75 & 33.3 & 46.4 & 19.5 \\
\hline & & Late & 414 & 663 & 1.76 & 35.6 & 47.3 & 18.6 \\
\hline & & LSD $(0.05)$ & ns & 26 & ns & 0.5 & ns & ns \\
\hline & Fukuyutaka & Normal & 405 & 800 & 1.68 & 30.2 & 46.7 & 19.3 \\
\hline & & Late & 438 & 720 & 1.77 & 34.5 & 46.3 & 19.0 \\
\hline & Sachiyutaka & Normal & 404 & 612 & 1.82 & 36.4 & 46.1 & 19.6 \\
\hline & & Late & 389 & 606 & 1.75 & 36.8 & 48.2 & 18.1 \\
\hline & & LSD $(0.05)$ & 18 & 36 & 0.05 & 0.7 & 0.7 & 0.4 \\
\hline \multirow[t]{11}{*}{$\mathrm{NT}^{\mathrm{a}}$} & Fukuyutaka & & 449 & 785 & 1.74 & 33.0 & 46.0 & 18.8 \\
\hline & Sachiyutaka & & 374 & 593 & 1.78 & 35.3 & 47.6 & 18.7 \\
\hline & LSD $(0.05)$ & & 36 & 42 & ns & 1.4 & 0.6 & ns \\
\hline & & Normal & 419 & 708 & 1.76 & 34.1 & 46.7 & 18.9 \\
\hline & & Late & 405 & 670 & 1.76 & 34.3 & 46.9 & 18.6 \\
\hline & & $\operatorname{LSD}(0.05)$ & ns & ns & ns & ns & ns & ns \\
\hline & Fukuyutaka & Normal & 459 & 841 & 1.71 & 31.9 & 46.3 & 18.7 \\
\hline & & Late & 439 & 729 & 1.76 & 34.2 & 45.7 & 19.0 \\
\hline & Sachiyutaka & Normal & 378 & 574 & 1.81 & 36.3 & 47.0 & 19.1 \\
\hline & & Late & 371 & 612 & 1.76 & 34.4 & 48.1 & 18.2 \\
\hline & & LSD $(0.05)$ & ns & 60 & ns & 2.0 & 0.9 & 0.5 \\
\hline
\end{tabular}

${ }^{\mathrm{a}} \mathrm{NT}$ means non-treated control.

${ }^{\mathrm{b}}$ When the ANOVA indicates significance $(\mathrm{P}<0.05)$, LSD is shown; ns indicates no significance.

was larger than that in late sowing. In Fukuyutaka, sowing time had no significant effect on oil content in any groundwater condition.

In 2010, protein content was higher in Sachiyutaka than in Fukuyutaka. Protein content tended to be lower in normal sowing time than in late sowing in all groundwater conditions. A significant $(\mathrm{P}<0.05)$ cultivar $\times$ sowing time interaction on protein contents was found in all groundwater conditions. The difference in protein content between Fukuyutaka and Sachiyutaka was larger in late sowing than in normal sowing time.

Oil content tended to be higher in Fukuyutaka than in 
Table 2. Effects of sowing time and cultivar on yield, yield components and seed components in at each groundwater level in 2010.

\begin{tabular}{|c|c|c|c|c|c|c|c|c|}
\hline Groundwater & Cultivar & Sowing time & $\begin{array}{l}\text { Yield } \\
\left(\mathrm{g} \mathrm{m}^{-2}\right) \\
\end{array}$ & $\begin{array}{l}\text { No. of filled } \\
\operatorname{pod} \mathrm{m}^{-2}\end{array}$ & $\begin{array}{c}\text { No. of seed } \\
\text { per pod }\end{array}$ & $\begin{array}{c}100 \text {-seed } \\
\text { weight }(\mathrm{g})\end{array}$ & $\begin{array}{c}\text { Protein content } \\
(\%) \\
\end{array}$ & $\begin{array}{c}\text { Oil content } \\
(\%) \\
\end{array}$ \\
\hline \multirow[t]{11}{*}{$20 \mathrm{~cm}$} & Fukuyutaka & & 252 & 550 & 1.62 & 28.8 & 43.2 & 20.7 \\
\hline & Sachiyutaka & & 293 & 551 & 1.65 & 31.9 & 45.4 & 20.1 \\
\hline & LSD (0.05) & & $19^{\mathrm{b}}$ & ns & ns & 1.8 & 0.5 & 0.3 \\
\hline & & Normal & 284 & 561 & 1.60 & 31.6 & 43.7 & 20.8 \\
\hline & & Late & 261 & 540 & 1.67 & 29.1 & 44.9 & 19.9 \\
\hline & & LSD $(0.05)$ & ns & ns & 0.05 & ns & 0.5 & 0.3 \\
\hline & Fukuyutaka & Normal & 272 & 579 & 1.53 & 30.8 & 43.0 & 21.0 \\
\hline & & Late & 233 & 521 & 1.70 & 26.7 & 43.3 & 20.3 \\
\hline & Sachiyutaka & Normal & 297 & 542 & 1.67 & 32.4 & 44.4 & 20.6 \\
\hline & & Late & 290 & 559 & 1.63 & 31.4 & 46.4 & 19.5 \\
\hline & & LSD (0.05) & 27 & 27 & 0.07 & ns & 0.6 & 0.4 \\
\hline \multirow[t]{11}{*}{$35 \mathrm{~cm}$} & Fukuyutaka & & 271 & 587 & 1.56 & 29.3 & 43.5 & 20.5 \\
\hline & Sachiyutaka & & 310 & 566 & 1.73 & 32.0 & 44.4 & 20.3 \\
\hline & LSD (0.05) & & 21 & ns & 0.08 & 0.7 & 0.6 & ns \\
\hline & & Normal & 290 & 555 & 1.65 & 32.0 & 43.8 & 20.7 \\
\hline & & Late & 291 & 598 & 1.65 & 29.3 & 44.1 & 20.1 \\
\hline & & LSD $(0.05)$ & ns & ns & ns & 0.7 & ns & ns \\
\hline & Fukuyutaka & Normal & 272 & 579 & 1.52 & 30.8 & 44.0 & 20.7 \\
\hline & & Late & 270 & 596 & 1.60 & 27.8 & 43.0 & 20.3 \\
\hline & Sachiyutaka & Normal & 308 & 530 & 1.77 & 33.1 & 43.5 & 20.8 \\
\hline & & Late & 313 & 601 & 1.70 & 30.8 & 45.2 & 19.8 \\
\hline & & LSD $(0.05)$ & ns & ns & ns & ns & 0.8 & ns \\
\hline \multirow[t]{11}{*}{$\mathrm{NT}^{\mathrm{a}}$} & Fukuyutaka & & 253 & 585 & 1.62 & 28.0 & 43.5 & 20.3 \\
\hline & Sachiyutaka & & 298 & 566 & 1.72 & 29.6 & 45.2 & 19.9 \\
\hline & LSD (0.05) & & 23 & ns & ns & 0.5 & 0.3 & ns \\
\hline & & Normal & 287 & 564 & 1.62 & 30.1 & 44.1 & 20.2 \\
\hline & & Late & 264 & 588 & 1.72 & 27.5 & 44.5 & 20.0 \\
\hline & & LSD $(0.05)$ & ns & ns & ns & 0.5 & 0.3 & ns \\
\hline & Fukuyutaka & Normal & 247 & 557 & 1.53 & 28.9 & 44.0 & 20.0 \\
\hline & & Late & 259 & 570 & 1.70 & 27.0 & 43.0 & 20.3 \\
\hline & Sachiyutaka & Normal & 327 & 613 & 1.70 & 31.2 & 44.2 & 20.6 \\
\hline & & Late & 268 & 562 & 1.73 & 27.9 & 46.1 & 19.4 \\
\hline & & LSD $(0.05)$ & 33 & ns & ns & 0.7 & 0.4 & 0.5 \\
\hline
\end{tabular}

${ }^{\mathrm{a}} \mathrm{NT}$ means non-treated control.

${ }^{\mathrm{b}}$ When the ANOVA indicates significance $(\mathrm{P}<0.05)$, LSD is shown; ns indicates no significance.

Sachiyutaka in all groundwater conditions and oil content in normal sowing time tended to be higher than those in late sowing in all groundwater conditions. The effect of sowing time on oil content was greater in Sachiyutaka than in Fukuyutaka.

\section{Discussion}

In Japan, soil moisture fluctuation from flooding to drought limits the soybean yield. A new irrigation system, FOEAS, was developed in 2005 (Wakasugi and Fujimori, 2009) to control groundwater level at various depths at any 
time. This removes the unfavorable environment (flooding or drought stress) for soybean production. FOEAS has been reported to increase soybean yield as compared with conventional cultivation (only natural rainfall) in the Kanto region, eastern Japan (Shimada et al., 2006, 2009, 2012). Although there are major differences in the climate, optimum growing season, cultivar, and cultivation method between southwestern Japan and the Kanto region, there is no information on soybean cultivation using FOEAS in southwestern Japan. To promote the use of FOEAS in southwestern Japan, it is necessary to investigate the effect of groundwater level on the growth and yield of soybean in this area. Consequently, we evaluated this effect in southwestern Japan. The groundwater level was maintained at depths of 20 and $35 \mathrm{~cm}$ (Fig. 2) in this study, according to the reports of Shimada et al. (2006, 2009, 2012), which showed that the groundwater levels of 20 and $32 \mathrm{~cm}$ in FOEAS increased nodule activity and photosynthetic parameters as compared with those in conventional cultivation, resulting in a higher seed yield. Although in previous field studies by Cooper et al. (1991) and Mejia et al. (2000), the groundwater levels were not kept constant and were affected by the rainfall, in the present study, FOEAS was used to keep the groundwater level at the target positions throughout the growth period (Fig. 2a, b). The drainage ability of our experimental field (NT plot) was high, and the effect of groundwater level on SWP was clear (Fig. 2c, d, e, f). SWP at depths of 10 and 30 $\mathrm{cm}$ in the $20-\mathrm{cm}$ plot was above $-10 \mathrm{kPa}$ throughout the growth period, regardless of the rainfall amount and pattern in the two years (Fig. 2c, d, e, f). Although SWP at a depth of $10 \mathrm{~cm}$ greatly fluctuated in the 35-cm plot (Fig. $2 \mathrm{c}, \mathrm{d})$, SWP at a depth of $30 \mathrm{~cm}$ was kept above $-10 \mathrm{kPa}$ in both years (Fig. 2e, f). SWP at a depth of $10 \mathrm{~cm}$ in the NT plot showed a similar trend as observed in the $35-\mathrm{cm}$ plot (Fig. 2c, d), but the SWP at a depth of $30 \mathrm{~cm}$ greatly fluctuated, especially in 2010 (Fig. 2f). The rainfall amount in 2010 was smaller than that in 2008. This might result in a larger fluctuation of SWP at a depth of $30 \mathrm{~cm}$ in the NT plot in 2010 than in 2008. The groundwater level in the 20and 35-cm plots fluctuated after late October in both years, probably because the irrigation water for the paddy fields surrounding our experimental fields was gradually reduced, resulting in an overall drawdown of groundwater level around our experimental fields. This can be confirmed by the fact that the groundwater level in the NT plot could not be observed around this period (Fig. 2a, b) (the measuring limit for the groundwater level was $55 \mathrm{~cm}$ in 2010). Because the growth stage had already reached about R7 in late October, the fluctuation of the groundwater level around this period might have little effect on seed yield.

Because there were three FOEASs in the experimental field, and groundwater level treatment could not be replicated within each year, the effect of groundwater control on growth and yield could not be statistically determined in this study. However, because FOEASs were constructed in the same field with uniform soil properties and the distance between FOEASs and NT plots was very close, we may be able to discuss the effect of groundwater level on growth and yield of soybean. Among the yield components, the 100-seed weight tended to be increased by groundwater level treatment in both years. In 2008, the 35-cm plot had the highest 100-seed weight in Sachiyutaka in the late-sowing, followed by the 20-cm and NT plots in this order (Table 1). In 2010, groundwater levels of 20 and $35 \mathrm{~cm}$ increased the 100-seed weight as compared with the NT plot. Mejia et al. (2000) reported that 100-seed weight grown with a groundwater level of 50 and $75 \mathrm{~cm}$ was larger than that grown without groundwater treatment. These results indicate that sub-irrigation treatments may increase 100 -seed weight. Although the reason why the groundwater control increased 100-seed weight was not clear, the reduction of individual seed weight by drought stress has been reported to be caused by the accelerated leaf senescence (Egli and Bruening, 2004). Indeed, the leaves in the NT plot senesced earlier than those in the 20- and 35$\mathrm{cm}$ plots and the days to maturity was earlier in the NT plot than in the 20- and 35-cm plots. On two year average, the number of days to maturity in the $20-, 35 \mathrm{~cm}$ and NT plots were 123, 122, and 121 d in normal-sown Fukuyutaka, 111, 111 and $110 \mathrm{~d}$ for late-sown Fukuyutaka, 114, 114 and $112 \mathrm{~d}$ in normal-sown Sachiyutaka, and 103, 103 and $101 \mathrm{~d}$ for late-sown Sachiyutaka (data not shown). Thus, one reason for the increase in 100-seed weight by ground water control might be that leaf senescence was delayed, resulting in more assimilate allocated to the seed in the 20 - and $35-\mathrm{cm}$ plots than in the NT plot. Further studies are needed to reveal the cultivation methods that will increase other yield components, such as the number of filled pods $\mathrm{m}^{-2}$ and the number of seeds per pod in FOEAS.

In normal sowing time, a consistent trend was not observed in Fukuyutaka in the 2-yr experiment (Tables 1 and 2); in 2008, the yield in the 35-cm plot tended to be lower than in the 20-cm and NT plots, but in 2010, the yield in the 20- and 35-cm plots was similar or higher than that in the NT plot. Thus, the benefit of FOEAS on yield was not clear in Fukuyutaka in normal sowing time. For late-sown Fukuyutaka, the yield was the lowest in the 20-cm plot in both years (Tables land 2). Therefore, the growers are recommended not to set the groundwater level at a depth of $20 \mathrm{~cm}$, when they sow seeds of Fukuyutaka in late July. In this way, the effect of FOEAS on the yield of Fukuyutaka differed with the sowing time and the benefit of the groundwater control by FOEAS for the yield of Fukuyutaka was unclear in this study. The inconsistent growth response of Fukuyutaka to groundwater level (Figs. 3 and 4) might support this consideration. The reason for 
this is probably that the groundwater level of the NT plot was relatively high, above $55 \mathrm{~cm}$, until late September. This value was much higher than that observed by Mejia et al. (2000). They reported that the soybean yield in fields where the groundwater level was kept at a depth of $75 \mathrm{~cm}$ was higher than in those under control conditions in which the groundwater level was below $100 \mathrm{~cm}$. Several researchers reported that the optimum groundwater level was at depths of 40 to $60 \mathrm{~cm}$ from the soil surface (Fukui et al., 1951; Seko et al., 1987). These findings suggest that severer water stress was not imposed on Fukuyutaka even in the NT plot, because the groundwater level existed at a depth of about $60 \mathrm{~cm}$. Our results demonstrated that there is little or no advantage of groundwater level control by FOEAS on the yield of Fukuyutaka, when the position of groundwater level is above $60 \mathrm{~cm}$ from the soil surface. Therefore, FOEAS may improve the yield of Fukuyutaka in fields that have much lower groundwater levels than the NT plot.

In Sachiyutaka, the yield tended to be higher in the 20and 35-cm plots than in the NT plot, except for the normal sowing time in 2010 (Tables 1 and 2). This result indicates that the groundwater level in the FOEAS had a beneficial effect on yield in Sachiyutaka. The growth response of Sachiyutaka to groundwater level showed the similar trend as in yield; LAI and SDW in the NT plot were lower than those in the 20-and 35-cm plots, except for normal sowing time in 2010 (Figs. 3 and 4). Therefore, the groundwater level between 20 and $35 \mathrm{~cm}$ seemed to increase the yield of Sachiyutaka, regardless of sowing time. Because the groundwater level at a depth of 20-cm decreased growth and yield of Sachiyutaka in 2010 (Table 2, Figs. 3 and 4), we recommend the grower of Sachiyutaka to keep the groundwater level below $20 \mathrm{~cm}$ from the soil surface. The groundwater level treatment by FOEAS was effective in Sachiyutaka, but the advantage was not clear in Fukuyutaka. Shimada et al. (2012) reported that groundwater level control to 20 and $32 \mathrm{~cm}$ increased yield of soybean (cv. Tachinagaha). Thus, there was a cultivar difference in the response to groundwater level. Although the reason for the cultivar difference was unclear in this study, we hypothesize that the cultivar difference in the response to groundwater level may be partially caused by the different characteristics of the root systems. Ayars et al. (2006) suggested that the ideal groundwater level would be close to the bottom of the crop root zone early in the season and would recede as the root zone develops. Because FOEAS can raise or lower the groundwater level at any time, it would be possible to control the groundwater level in accordance with root growth.

Yield and yield components varied with the year (Tables 1 and 2), and the yields of Fukuyutaka and Sachiyutaka in 2010 were, respectively, $40.4 \%$ and $23.2 \%$ lower than those in 2008, although such a large reduction was not observed in shoot growth (Figs. 3 and 4). The weather in 2010 was characterized by much higher temperatures from middle August to middle September in comparison to 2008 (Fig. 1). During this period, the mean $\left(28.4^{\circ} \mathrm{C}\right)$, daily maximum $\left(33.3^{\circ} \mathrm{C}\right)$ and daily minimum temperatures $\left(24.9^{\circ} \mathrm{C}\right)$ were about $2^{\circ} \mathrm{C}$ higher in 2010 than in 2008, and this period corresponded to R1 to R3 of both cultivars. During flowering and pod set, temperatures as high as $30 / 20^{\circ} \mathrm{C}$ (day/night) were favorable for pod set, but temperatures above $40^{\circ} \mathrm{C}$ severely decreased pod formation (Mann and Jaworski, 1970). Seed formation was decreased as the day temperature increased from $30^{\circ} \mathrm{C}$ to $35^{\circ} \mathrm{C}$ (Gibson and Mullen, 1996). Temperatures above $30 / 25^{\circ} \mathrm{C}$ during pod development reduced the seed weight, regardless of the temperature during seed fill (Egli and Wardlaw, 1980). These findings may support our finding that the number of filled pods $\mathrm{m}^{-2}$ and the 100-seed weight were smaller in 2010 than in 2008 (Tables 1 and 2). Although it was reported that the number of seeds per pod was least affected by temperature (Huxley et al., 1976; Sionit et al., 1987; Baker et al., 1989), the number of seeds per pod was also smaller in 2010 than in 2008 in this study (Tables 1 and 2). These observations confirmed that the higher temperatures in 2010 negatively affected all yield components, resulting in a lower yield. The degree of yield reduction varied with the cultivar, indicating the existence of a cultivar difference in the tolerance to hot air temperature.

In both years, the main effects of cultivar and sowing time on protein and oil contents were observed in all groundwater conditions, although the differences in protein and oil contents among these factors were less than $2 \%$. The effect of groundwater level on the protein and oil contents varied with the year and a consistent effect was not detected. Shimada et al. (2012) also reported that there was no consistent trend in the effect of groundwater level on the protein and oil contents and the difference in protein and oil contents among groundwater level treatments was less than $1.5 \%$. These small differences may not influence the market value of soybean seeds. Overall, our findings suggest that seed components are not affected greatly by groundwater level treatment administered using FOEAS.

In conclusion, the effects of groundwater level on growth and yield might differ with the cultivar used. The growth and yield of Sachiyutaka might be increased by FOEAS, especially in late sowing, although the advantage of FOEAS was not clear in Fukuyutaka. Future studies should reveal (1) the optimum groundwater level in each cultivar and (2) the physiological and morphological traits that are responsible for the cultivar difference in the response to FOEAS. The cultivar differences in growth and yield in response to FOEAS may be considered to be caused by the different characteristics of the root systems. Studies on the cultivar difference in root growth in the response to groundwater level will be reported in future. 


\section{Acknowledgements}

We are grateful to Dr. S. H. Zheng (Saga University) for his valuable advice on this experiment. We thank the field managers of KARC for their technical support of experimental field management.

\section{References}

Araki, H. 2006. Water uptake of soybean (Glycine max L. Merr.) during exposure to $\mathrm{O}_{2}$ deficiency and field level $\mathrm{CO}_{2}$ concentration in the root zone. Field Crops Res. 96: 98-105.

Arihara, J., Tian, X., Nakayama, N., Saito, Y. and Kanno, A. 2000. Crop specific difference in growth and yield caused by low oxygen stress during germination. In Abstract of the 3rd Int. Crop Sci. Cong. Hamburg, Germany, 59.

Ayars, J.E., Christen, E.W., Soppe, R.W. and Meyer, W.S. 2006. The resource potential of in-situ shallow ground water use in irrigated agriculture: a review. Irrig. Sci. 24: 147-160.

Baker, J.T., Allen, L.H.Jr., Boote, K.J., Jones, P. and Jones, J.W. 1989. Response of soybean to air temperature and carbon dioxide concentration. Crop Sci. 29: 98-105.

Cooper, R.L., Fausey, N.R. and Streeter, J.G. 1991. Yield Potential of soybean grown under a subirrigation/drainage water management system. Agron. J. 83: 884-887.

Egli, D.B. and Wardlaw, I.F. 1980. Temperature response of seed growth characteristics of soybeans. Agron. J. 72: 560-564.

Egli, D.B. and Bruening, W.P. 2004. Water stress, photosynthesis, seed sucrose levels and seed growth in soybean. J. Agric. Sci. 142: 1-8.

Fehr, W.R., Caviness, C.E., Burmood, D.T. and Pennington, J.S. 1971. Stage of development descriptions for soybeans, Glycine max (L.) Merrill. Crop Sci. 11: 929-931.

Fukui, J., Ito, R. and Uchiyama, Y. 1951. Influence of soil moisture content on the growth and yield of soy-bean. III. Influence of high and low level of underground water upon the growth and yield of soy-bean. J. Kanto-Tosan Agric. Exp. Stn. 1: 9-16***.

Gibson, L.R. and Mullen, R.E. 1996. Influence of day and night temperature on soybean seed yield. Crop Sci. 36: 98-104.

Hamaya, K., Ishida, M., Oka, H., Haruna, K., Isobe K. and Ishii, R. 2007. Effects of high ground-Water level on the growth and yield of supernodulating soybean cultivar, Sakukei 4 II. Effects of high ground-water level on nitrogen absorption. Plant Prod. Sci. 10: 478480.

Hunter, M.N., De Jabrun, P.L.M. and Byth, D.E. 1980. Response of nine soybean lines to soil moisture conditions close to saturation. Aust. J. Exp. Agric. Anim. Husb. 20: 339-345.

Huxley, P.A., Summerfield, R.J. and Hughes, A.P. 1976. Growth and development of soybean cv. TK5 as affected by tropical daylengths, day/night temperatures and nitrogen nutrition. Ann. Appl. Biol. 82: 117-133.

Mann, J.D. and Jaworski, E.G. 1970. Comparison of stresses which may limit soybean yields. Crop Sci. 10: 620-624.

Mejia, M.N., Madramootoo, C.A. and Broughton, R.S. 2000. Influence of water table management on corn and soybean yields. Agric. Water Manage. 46: 73-89.

Murphy, P.A., Chen, H.P., Hauck, C.C., Wilson, L.A. and Giese, J. 1997. Soybean protein composition and tofu quality. Food Technol.
51: 86-88.

Nathanson, K., Lawn, R.J., De Jabrun, P.L.M. and Byth, D.E. 1984. Growth, nodulation and nitrogen accumulation by soybean in saturated soil culture. Field Crops Res. 8: 73-92.

Seko, H., Samura, T., Kagotani, H., Futami, K., Yoshikura, J., Sawada, T. and Aoyama, Y. 1987. Stable high yield cultivation of soybean in underdrained rotational upland field. III. Effects of undergroundwater level and watering in growth and yield of soybean. Bull. Hyogo. Prefect. Agric. Cent. Exp. Ext. Educ. 35: 21-24***.

Shimada, S., Kokubun, M. and Matsui, S. 1995. Effects of water table on physiological traits and yield of soybean (Glycine max). I. Effects of water table and rainfall on leaf chlorophyll content, root growth and yield. Jpn. J. Crop Sci. 64: 294-303*.

Shimada, S., Kokubun, M. and Matsui, S. 1997. Effects of water table on physiological traits and yield of soybean (Glycine max). II. Effects of water table and rainfall on leaf water potential and photosynthesis. Jpn.J. Crop Sci. 66: 108-117*.

Shimada, S., Fujimori, S., Wakasugi, K., Kanzaki, M., Haraguchi, S., Nohara, T., Nakamura, T., Nakayama, N., Yamamoto, R. and Shimamura, S. 2006. Effect of new underground irrigation system (FOEAS) on establishment, nitrogen fixation and yield of soybean cultivars. Jpn. J. Crop Sci.75 (Extra issue 1): 98-99**.

Shimada, S., Hamaguchi, H., Kato, M., Kokuryu, T., Wakasugi, K. and Fujimori, S. 2009. Effect of FOEAS on soybean production in a large-scale field. Jpn. J. Crop Sci. 78 (Extra issue 2): 78-79**.

Shimada, S., Hamaguchi, H., Kim, Y., Matsuura, K., Kato, M., Kokuryu, T., Tazawa, J. and Fujimori, S. 2012. Effects of water table control by farm-oriented enhancing aquatic system on photosynthesis, nodule nitrogen fixation, and yield of soybeans. Plant Prod. Sci. 15: 132-143.

Sionit, N., Strain, B.R. and Flint, E.P. 1987. Interaction of temperature and $\mathrm{CO}_{2}$ enrichment on soybean: Photosynthesis and seed yield. Can. J. Plant Sci. 67: 629-636.

Uchikawa, O., Fukushima, Y. and Matsue, Y. 2003. Statistical analysis of soybean yield and meteorological conditions in the northern Kyushu. Jpn. J. Crop Sci. 72: 203-209***.

Uchikawa, O., Tanaka, K., Miyazaki, M. and Matsue, Y. 2009. Effects of planting pattern on growth, yield and nitrogen fixation activity of soybean cropped with late planting and non-intertillage cultivation method in northern Kyusyu. Jpn. J. Crop Sci. 78: 163$169^{* * * *}$.

Wada, T., Endo, N. and Takahashi, M. 2006. Reducing seed damage by soybean bugs by growing small-seeded soybeans and delaying sowing time. Crop Prot. 25: 726-731.

Wakasugi, K. and Fujimori, S. 2009. Subsurface water level control system "FOEAS" that promotes the full use of paddy fields. J. Jpn. Soc. Irrig. Drainage Rural Eng. 77: 705-708****.

Zarkadas, C.G., Voldeng, H.D., Yu Z.R., Shang, K. and Pattison, P.L. 1997. Comparison of the protein quality of five new northern adapted natto soybean cultivars by amino acid analysis. J. Agric. Food Chem. 45: 2013-2019.

\footnotetext{
* In English with Japanese abstract.

** In Japanese with English title.

*** In Japanese with English abstract.

***** In Japanese.
} 